The Free Internet Journal

for Organic Chemistry
Paper

Arkivoc 2018, part ii, 97-113

Archive for

Organic Chemistry

\title{
Generation and reactions of thiirenium ions by the Cation Pool method
}

\author{
Akihiro Shimizu, ${ }^{a}$ Shun Horiuchi, ${ }^{a}$ Ryutaro Hayashi, ${ }^{a}$ Kouichi Matsumoto, ${ }^{b}$ Yu Miyamoto, ${ }^{b}$ \\ Yusuke Morisawa, ${ }^{\text {b }}$ Tomonari Wakabayashi, ${ }^{b}$ and Jun-ichi Yoshida*a \\ ${ }^{a}$ Department of Synthetic Chemistry and Biological Chemistry, Graduate School of Engineering, \\ Kyoto University, Nishikyo-ku, Kyoto 615-8510, Japan \\ ${ }^{b}$ Department of Chemistry, School of Science and Engineering, Kindai University, Kowakae 3-4-1, \\ Higashi-Osaka, Osaka 577-8502, Japan \\ Email: yoshida@sbchem.kyoto-u.ac.jp
}

\section{Dedicated to Professor Kenneth Laali on the occasion of his 65th anniversary}

Received 08-13-2017

Accepted 10-28-2017

Published on line 11-05-2017

\section{Abstract}

Thiirenium ions generated and accumulated by low-temperature electrochemical oxidation of disulfides in the presence of alkynes were successfully observed by low-temperature NMR, Raman, and mass spectroscopies and were found to be stable at temperatures below $-40{ }^{\circ} \mathrm{C}$. The thiirenium ions showed ambident reactivity toward subsequently added nucleophiles to give either disubstituted alkenes or alkynes depending on the nature of the nucleophiles.

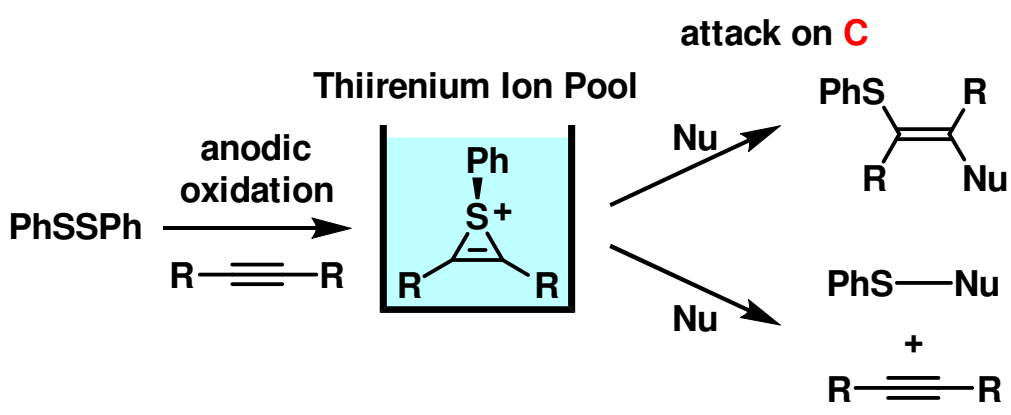

attack on $\mathrm{S}$

Keywords: Electrosynthesis, cations, thiirenium ions, reactive intermediates, ambident reactivity 


\section{Introduction}

Thiirenium ions ${ }^{1}$ are important reactive intermediates in difunctionalization of alkynes. Because of their instability, thiirenium ions are conventionally generated by the reaction of alkynes with $\mathrm{RS}^{+}$equivalents in special solvents such as liquid $\mathrm{SO}_{2} .{ }^{2-5}$ Some thiirenium ions having bulky substituent groups can be isolated and characterized by X-ray crystal structural analysis. ${ }^{6}$ Recently, Poleschner et al. reported the synthesis of thiirenium ions in $\mathrm{CH}_{2} \mathrm{Cl}_{2}$ by the reaction of disulfides with alkynes having bulky substituent groups using $\mathrm{XeF}_{2}$ as an one-electron oxidant and silylcarborate salt $\mathrm{Me}_{3} \mathrm{Si}^{+} \mathrm{CHB}_{11} \mathrm{Cl}_{11}{ }^{-}$as a $\mathrm{F}^{-}$acceptor. ${ }^{7}$ However, generation and accumulation of the thiirenium ions which do not have bulky substituent groups in normal organic solvents are still challenging ${ }^{8}$ because nucleophiles derived from the $\mathrm{RS}^{+}$equivalents such as $\mathrm{Cl}^{-}$and MeSSMe reacts with thiirenium ions even at low temperatures and even in highly acidic media. ${ }^{2-5}$ Also, their generation in the presence of strong nucleophiles prevents studies on their reactivity towards various nucleophiles. Therefore, there is still room for a method for generating and accumulating thiirenium ions in normal organic solvents in the absence of strong nucleophiles.

Electrochemical oxidation ${ }^{9-15}$ serves as a powerful method for generating and accumulating highly reactive cationic species. (For recent papers on organic electrosynthesis, see for example, refs 16-18) Electrochemical oxidation in solvents normally used in organic syntheses can be carried out by the cation pool method. ${ }^{19-21}$ We have reported that the electrochemical oxidation of diaryl disulfides (ArSSAr) leads to the formation of $\operatorname{ArS}(\mathrm{ArSSAr})^{+}$, which can be accumulated in solution at low temperatures (Figure 1). ${ }^{22-26}$ This reaction presumably proceeds by generation of "ArS" followed by its reaction with ArSSAr. Therefore, we envisaged that the anodic oxidation of ArSSAr in the presence of alkynes leads to the formation of thiirenium ions (Figure 1). The method would enable not only characterization of thiirenium ions but also a study of their reactivity towards various nucleophiles which can be added after their generation. Herein, we report the generation of thiirenium ions having no bulky substituent groups by the "cation pool" method, their spectroscopic characterization, and their reactions with subsequently added nucleophiles.

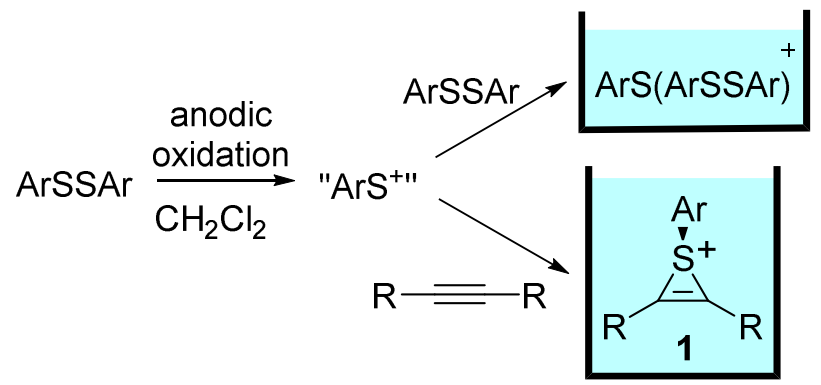

Figure 1. Generation and accumulation of $\operatorname{ArS}(\operatorname{ArSSAr})^{+}$and thiirenium ions.

\section{Results and Discussion}

To generate and accumulate thionium ion 1a $(\mathrm{Ar}=\mathrm{Ph}, \mathrm{R}=\mathrm{Pr})$, electrochemical oxidation of PhSSPh (2) in the presence of 4-octyne was carried out under constant current conditions at $-78{ }^{\circ} \mathrm{C}$ in an $\mathrm{H}$-type divided cell equipped with an anode consisting of fine carbon fibers and a platinum plate cathode in $0.3 \mathrm{M} \mathrm{Bu}_{4} \mathrm{PBF}_{4} / \mathrm{CD}_{2} \mathrm{Cl}_{2}$ (Figure S1). ${ }^{27}$ After $2.1 \mathrm{~F}$ of electricity was applied, the resulting anodic solution was analyzed by ${ }^{1} \mathrm{H}$ and ${ }^{13} \mathrm{C}$ NMR spectroscopies at $-78{ }^{\circ} \mathrm{C}$ (Figure 2). In the ${ }^{1} \mathrm{H}$ and ${ }^{13} \mathrm{C}$ NMR spectra no signal of the disulfide 2 was observed. Only signals which can be attributed to 1a were observed. All signals were assigned as shown in 
Figure 2 by using HMQC and HMBC measurements (Figures S2 and S3). Correlation between $\mathrm{H}_{a, \mathrm{a}^{\prime}}$ and $\mathrm{H}_{o, m}$ in NOE spectrum (Figure S4) indicates the generation and accumulation of thiirenium ion 1a in the solution. The chemical shift of the alkenyl carbons $(106.8 \mathrm{ppm})$ is consistent with those of a thiirenium ion having tert-butyl groups reported in the literature $\left(114.52^{6}\right.$ and $\left.113.17^{7}\right)$. Notably, two signals assigned to $H_{a}$ and $H_{a^{\prime}}$ and two signals assigned to $\mathrm{H}_{\mathrm{b}}$ and $\mathrm{H}_{\mathrm{b}}$, were observed at around 3.0 and $1.7 \mathrm{ppm}$, respectively (Figure 2a, inset), indicating that 1a has a pyramidal sulfur atom whose inversion is prohibited or slow compared to the NMR time scale. The pyramidal structure of $1 \mathbf{a}$ is consistent with the reported X-ray structure of the thiirenium ions bearing bulky tert-butyl groups. ${ }^{6,7}$

a)

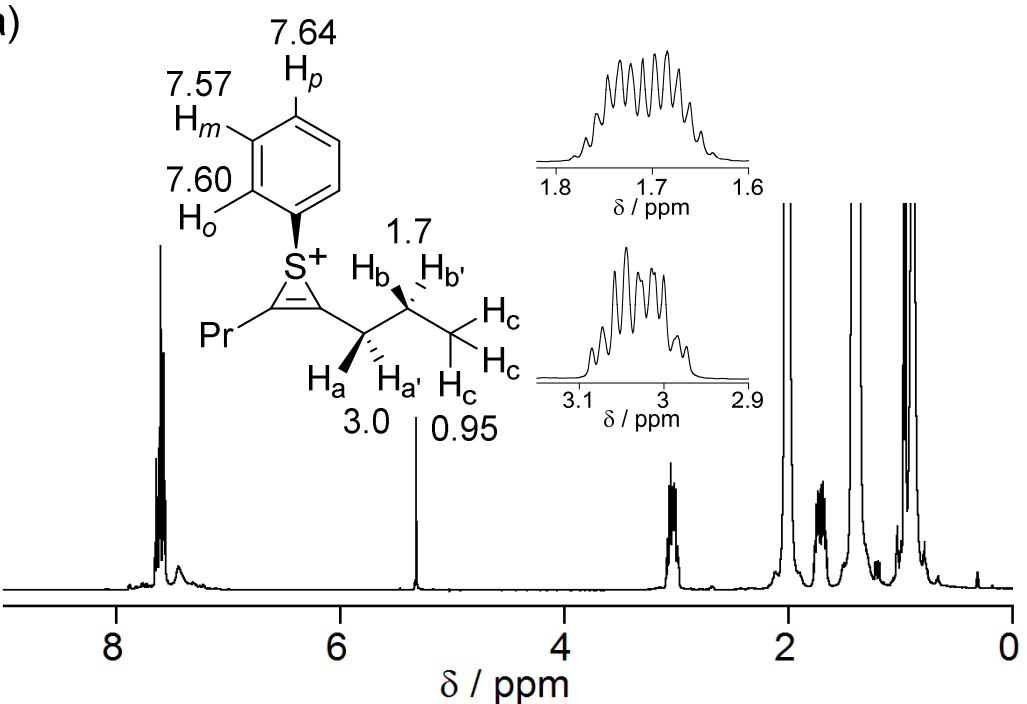

b)

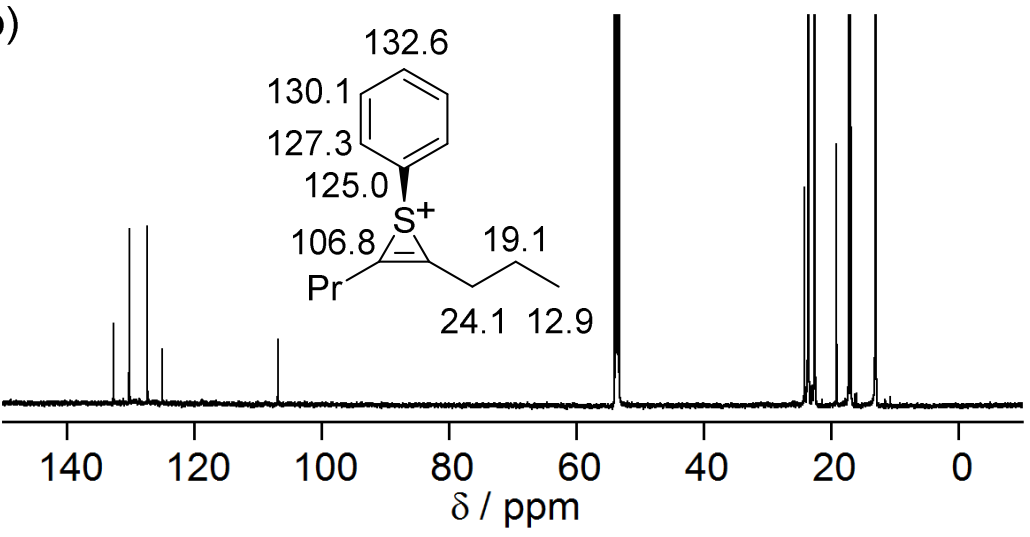

Figure 2. a) ${ }^{1} \mathrm{H} N M R$ and b) ${ }^{13} \mathrm{C} N M R$ spectra of $1 \mathrm{a}$ at $-78{ }^{\circ} \mathrm{C}$ in $\mathrm{Bu}_{4} \mathrm{PBF}_{4} / \mathrm{CD}_{2} \mathrm{Cl}_{2}$.

Thiirenium ion 1a generated in $\mathrm{Bu}_{4} \mathrm{NB}\left(\mathrm{C}_{6} \mathrm{~F}_{5}\right)_{4} / \mathrm{CH}_{2} \mathrm{Cl}_{2}$ instead of $\mathrm{Bu}_{4} \mathrm{PBF}_{4} / \mathrm{CD}_{2} \mathrm{Cl}_{2}$ was analyzed by coldspray-ionization mass spectroscopy $(\mathrm{CSI}-\mathrm{MS})^{28}$ at $0{ }^{\circ} \mathrm{C} .^{29}$ The signal assigned to 1 a was successfully observed (Figure S5).

Raman spectra were measured during the electrochemical oxidation at $-78{ }^{\circ} \mathrm{C}$ (Figure $3 a$ ). ${ }^{30,31}$ The solution of $\operatorname{ArSSAr}\left(\mathrm{Ar}=4-\mathrm{FC}_{6} \mathrm{H}_{4}\right)$ and 4-octyne in $\mathrm{Bu}_{4} \mathrm{NBF}_{4} / \mathrm{CH}_{2} \mathrm{Cl}_{2}$ was electrochemically oxidized to give $\mathbf{1 b}(\mathrm{Ar}=4$ $\left.\mathrm{FC}_{6} \mathrm{H}_{4}, \mathrm{R}=\mathrm{Pr}\right) .{ }^{32}$ Increase of the electricity applied strengthened the signal at $1874 \mathrm{~cm}^{-1}$, which is assigned to the stretching of the $\mathrm{C}-\mathrm{C}$ double bond of $\mathbf{1 b}$ by DFT calculations $\left(1862 \mathrm{~cm}^{-1}\right.$, scaling factor: $\left.0.9614^{33}\right)$. The vibration frequencies of the $\mathrm{C}-\mathrm{C}$ triple bond of 4-octyne, the $\mathrm{C}-\mathrm{C}$ double bond of $\mathbf{1 b}$, and the $\mathrm{C}-\mathrm{C}$ double bond of cis-4-octene show linear correlation with the $\mathrm{C}-\mathrm{C}$ bond lengths obtained by DFT calculations (Figure $3 \mathrm{~b}$ ), 
which is similar to the tendency of seleniranium ions reported in the literature. ${ }^{34}$ The higher frequency and the shorter bond length of $\mathbf{1 b}$ than those of cis-4-octene is not because of the bond order of the $\mathrm{C}-\mathrm{C}$ double bond of $\mathbf{1 b}(1.91)$ and cis-4-octene (1.93) but because of the higher s-character of the carbon atoms of $\mathbf{1 b}(41.1 \%$, $\left.\mathrm{sp}^{1 \cdot 43}\right)$ than that of cis-4-octene $\left(39.5 \%, \mathrm{sp}^{1.53}\right)$.

a)

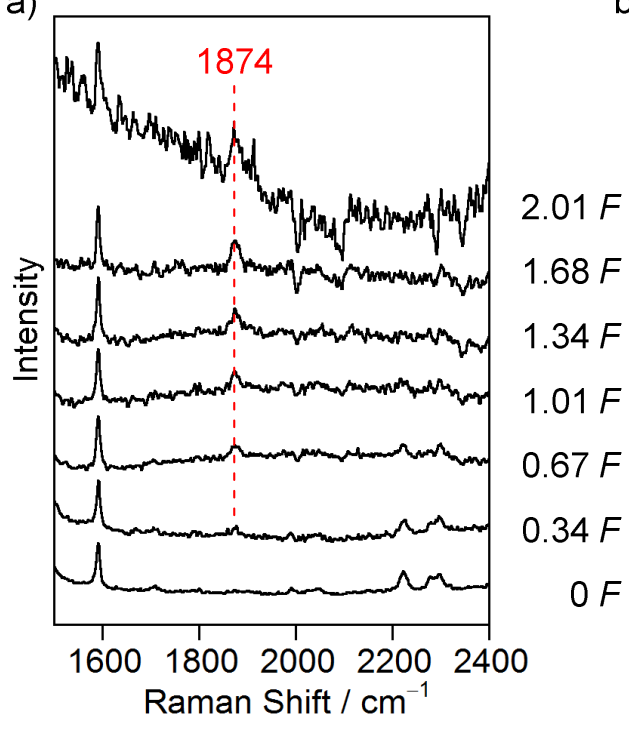

b)

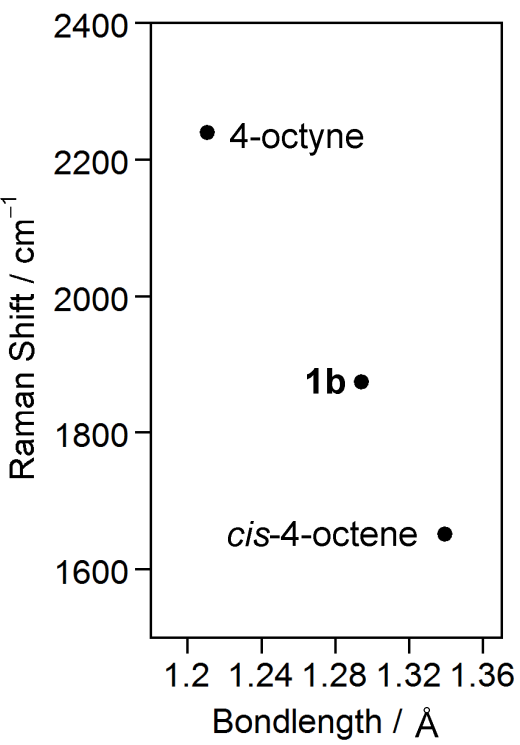

Figure 3. (a) Raman spectra of the reaction mixture during anodic oxidation at $-78{ }^{\circ} \mathrm{C}$ in $\mathrm{Bu}_{4} \mathrm{NBF}_{4} / \mathrm{CH}_{2} \mathrm{Cl}_{2}$. (b) Relation between the observed $\mathrm{C}-\mathrm{C}$ vibrations and $\mathrm{C}-\mathrm{C}$ bond lengths obtained by DFT calculations of 4-octyne, $\mathbf{1 b}$, and cis-4-octene.

The thermal stability of thiirenium ion 1a was investigated. ${ }^{35}$ After a solution of 1a was kept at the second temperature for $30 \mathrm{~min}$, the resulting solution was recooled to $-78{ }^{\circ} \mathrm{C}$. Then, $\mathrm{Bu}_{4} \mathrm{NCl}(10$ equiv) was added and the mixture was stirred at $-78{ }^{\circ} \mathrm{C}$ for $30 \mathrm{~min}$. After work-up the yields of products, chloro-substituted alkene $\mathbf{2 a}$ and fluoro-substituted alkene $\mathbf{2} \mathbf{b}$ were determined by gas chromatography. Plots of the yield of $\mathbf{2 a}$ against the temperature (Figure 4) indicates that $1 \mathrm{a}$ is stable at temperatures lower than $-40{ }^{\circ} \mathrm{C}$. At the temperatures higher than $-20{ }^{\circ} \mathrm{C}$, the yield of $\mathbf{2 a}$ decreased and the yield of $\mathbf{2} \mathbf{b}$ increased with an increase in the temperature. Presumably, alkene $\mathbf{2} \mathbf{b}$ was produced by the reaction of $\mathbf{1 a}$ with the supporting electrolyte $\mathrm{BF}_{4}{ }^{-}$ (vide infra).

Reactions of thiirenium ion 1a with various nucleophiles were investigated (Table 1). After electrochemical generation and accumulation of the thiirenium ion, a nucleophile was added to the solution. The resulting solution was stirred at $-78{ }^{\circ} \mathrm{C}$ for $30 \mathrm{~min}$ and then at $20^{\circ} \mathrm{C}$ for $30 \mathrm{~min}$. Cl reacted with $1 \mathrm{a}$ to give $2 \mathrm{a}$ in a good yield. When a nucleophile was not added intentionally, $\mathbf{2 b}$ was obtained in a good yield (entry 2 ). Presumably $\mathrm{F}^{-}$derived $\mathrm{BF}_{4}^{-}$reacted with 1a. $\mathrm{Br}^{-}, \mathrm{I}^{-}, \mathrm{ArO}^{-}\left(\mathrm{Ar}=4-\mathrm{O}_{2} \mathrm{~N}-\mathrm{C}_{6} \mathrm{H}_{4}\right), \mathrm{AcO}^{-}, \mathrm{TfO}^{-}$, and $\mathrm{SCN}^{-}$, reacted with $1 \mathrm{a}$ to give the corresponding substituted alkenes $\mathbf{2 c}-\mathbf{2} \mathbf{h}$ (entries 3-8). Stereochemistry of the alkenes was determined to be $E$ by the NOE measurements. $\mathrm{MeOH}$ reacted with 1 a to give ketone 4 , which was probably formed via methoxy alkene (entry 9). Lithium acetylide gave a mixture of $\mathbf{2} \mathbf{i}$ and $\mathbf{3 a}$ (entry 10 ). Enyne $\mathbf{2} \mathbf{i}$ was formed by the nucleophilic attack of the acetylide on $\mathrm{C}$, whereas phenylthio-substituted alkyne 3a was formed by the attack of the acetylide on S. Dimethylketene methyl trimethylsilyl acetal and $\mathrm{Et}_{2} \mathrm{NH}$ attacked the sulfur atom of $1 \mathrm{a}$ to give compounds $\mathbf{3 b}$ and $\mathbf{3 c}$, respectively (entries 11 and 12). Recovery of the alkyne was confirmed by the 
reaction using 8-hexadecyne and $\mathrm{Et}_{2} \mathrm{NH}$ (entry 13). These results indicate that $\mathbf{1 a}$ acts as an ambident electrophile. $^{36}$

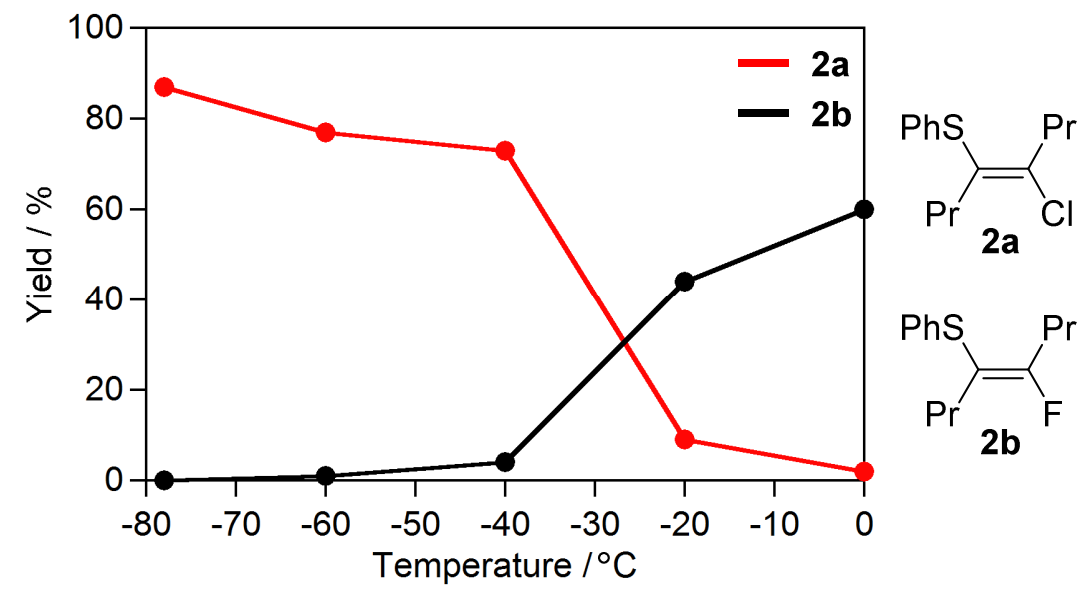

Figure 4. Thermal stability of the thiirenium ion $\mathbf{1 a}$ in $\mathrm{Bu}_{4} \mathrm{NBF}_{4} / \mathrm{CH}_{2} \mathrm{Cl}_{2}$. Yields of $\mathbf{2 a}$ (red line) and $\mathbf{2 b}$ (black line).

Table 1. Reactions of thiirenium ion 1a with nucleophiles ${ }^{a}$

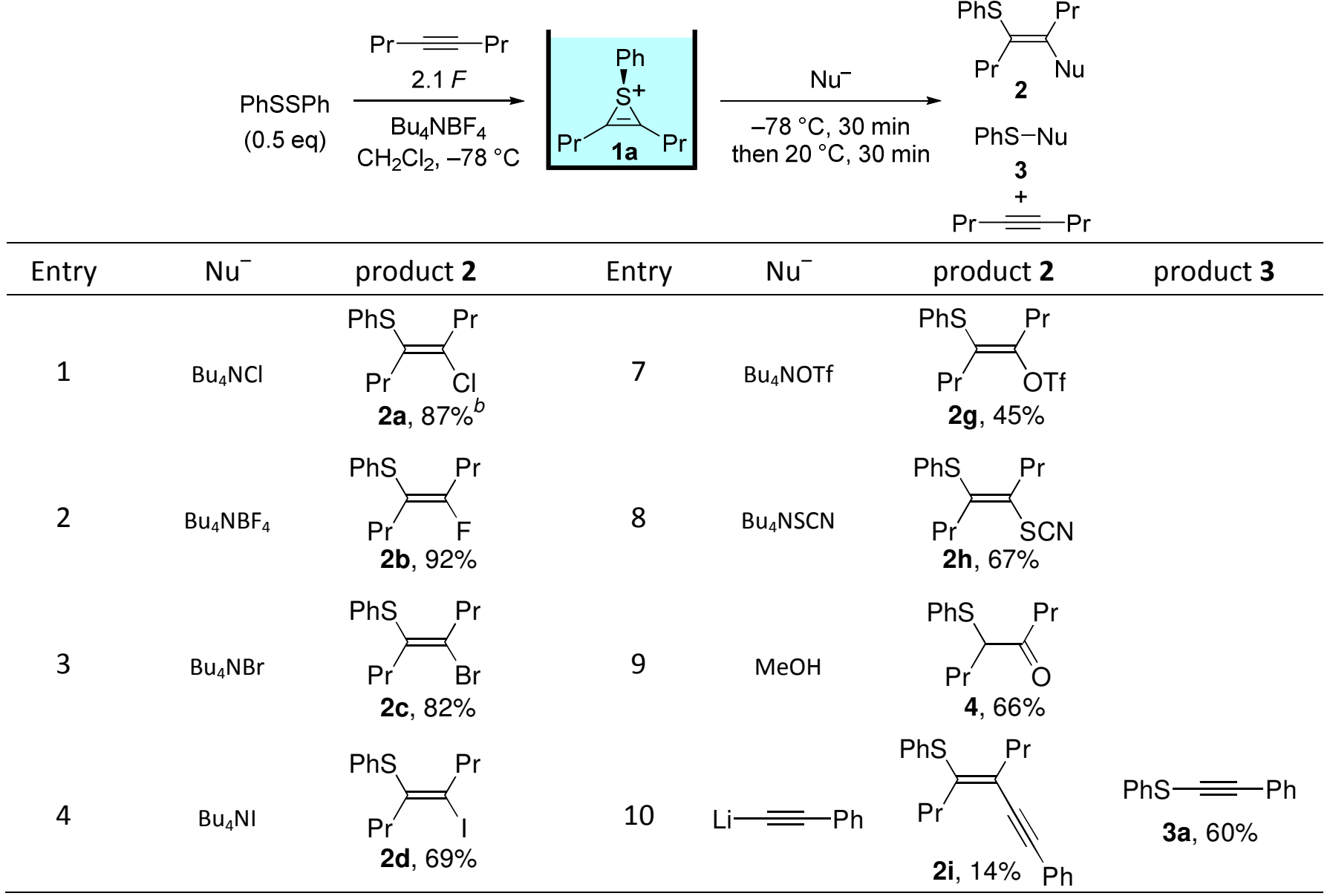


Table 1. Continue

\begin{tabular}{|c|c|c|c|c|c|c|}
\hline Entry & $\mathrm{Nu}^{-}$ & product 2 & Entry & $\mathrm{Nu}^{-}$ & product 2 & product 3 \\
\hline 5 & $\begin{array}{c}\mathrm{Bu}_{4} \mathrm{NOAr}^{\mathrm{c}} \\
\mathrm{Ar}=\mathrm{C}_{6} \mathrm{H}_{4} \mathrm{NO}_{2}-4\end{array}$ & $\begin{array}{c}\mathrm{Pr} \quad \mathrm{OAr} \\
\mathbf{2 e}, 40 \%\end{array}$ & 11 & $\mathrm{OMe}$ & & $\underbrace{O}_{3 b, 50 \%}$ \\
\hline \multirow[b]{2}{*}{6} & \multirow[b]{2}{*}{$\mathrm{Bu}_{4} \mathrm{NOAC}$} & & 12 & $\mathrm{Et}_{2} \mathrm{NH}$ & & $\begin{array}{c}\mathrm{PhS}-\mathrm{NEt}_{2} \\
3 \mathbf{c}, 58 \%\end{array}$ \\
\hline & & $\begin{array}{c}\mathrm{Pr} \quad \mathrm{OAc} \\
\mathbf{2 f}, 61 \%\end{array}$ & $13^{d}$ & $\mathrm{Et}_{2} \mathrm{NH}$ & & $\begin{array}{c}\mathrm{PhS}-\mathrm{NEt}_{2} \\
\mathbf{3 c}, 82 \%\end{array}$ \\
\hline
\end{tabular}

${ }^{a}$ PhSSPh $(0.125 \mathrm{mmol})$ was electrochemically oxidized $(2.1 \mathrm{~F})$ in the presence of 4-octyne $(0.25 \mathrm{mmol})$ in a $0.3 \mathrm{M}$ solution of $\mathrm{Bu}_{4} \mathrm{NBF}_{4}$ in $\mathrm{CH}_{2} \mathrm{Cl}_{2}$ at $-78^{\circ} \mathrm{C}$. 10 equiv of nucleophile was added. Isolated yields are shown unless otherwise stated.

${ }^{\mathrm{b}}$ The yields were determined by GC using an internal standard. ${ }^{\mathrm{c}} 7.1 \mathrm{eq}$ of $\mathrm{Bu}_{4} \mathrm{NOAr}$ was added. ${ }^{\mathrm{d}}$ 8-Hexadecyne was used instead of 4-octyne. $94 \%$ of 8-hexadecyne was recovered.

To obtain a deeper insight into the reactivity of the thiirenium ion we carried out DFT calculations. These calculations show that the LUMO of 1a has large coefficients on the sulfur and the two carbon atoms of the three-membered ring (Figure 5a), indicating that nucleophiles can attack both sulfur and carbon atoms. The DFT calculation also shows that the carbon atom has higher positive potential than the sulfur atom although the thiirenium ion formally has a positive charge on the sulfur atom (Figure 5b).
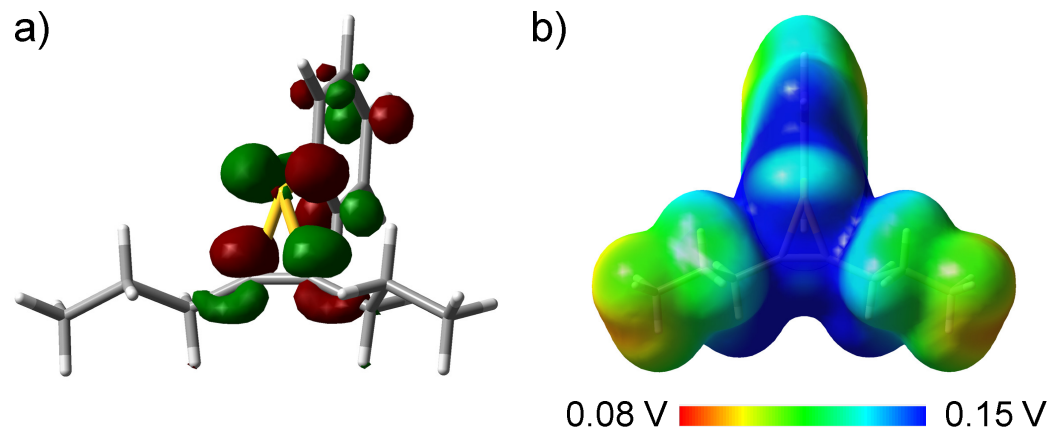

Figure 5. a) LUMO and b) electrostatic potential of 1a.

The following mechanistic arguments may be reasonable (Figure 6). The ketene silyl acetal and $\mathrm{Et}_{2} \mathrm{NH}$ attack the sulfur atom, which has a formal positive charge, to give $\mathbf{3}$ and the acetylene (path $a)$, whereas halide, acetate, triflate, and SCN anions and methanol attack the carbon atom to give $\mathbf{2}$ (path $b$ ). The lithium acetylide attacks both the carbon and sulfur atoms of $\mathbf{1}$. In the case of halide, acetate, and triflate ions as nucleophiles the reverse reaction of path a might be possible, because such nucleophiles are also good leaving groups. If such an equilibrium exists, $\mathbf{2}$ can be produced even if path $a$ is preferable. To examine such a possibility, the experiments using an externally added acetylene having different $\mathrm{R}$ groups were carried out. The equilibrium would lead to the exchange of acetylenes and the formation of thiirenium ion 1 with different R groups, which eventually gives $\mathbf{2}$ with different $\mathrm{R}$ groups. 


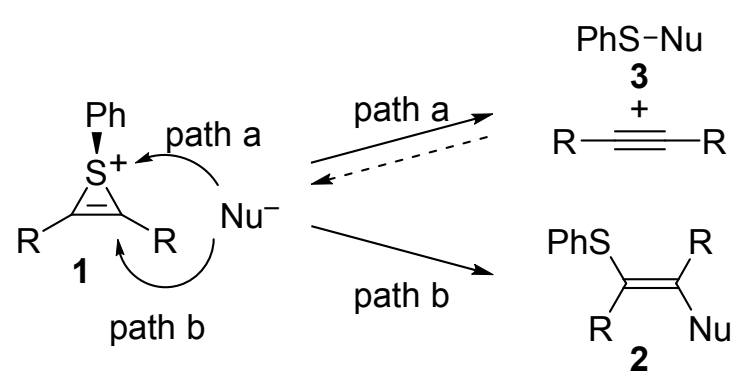

Figure 6. Plausible explanation for the product selectivity.

5-Decyne (1 equiv) was added to a solution of $1 \mathrm{a}$ and the mixture was reacted with $\mathrm{Bu}_{4} \mathrm{NCl}$. $2 \mathrm{a}$ was obtained as the major product (68\%) in addition to $\mathbf{2 j}(14 \%)$ (Figure 7 ). The reaction via path a gives 3 and 4 octyne, which might go out of the solvent cage. The reverse reaction of $\mathbf{3}$ with 5-decyne in the bulk solution gives $1 \mathbf{c}$, which react with $\mathrm{Cl}^{-}$via path $b$ to give $\mathbf{2 j}$. This means the equilibrium discussed above does exist, although it does not play a major role. Another possibility to be considered is that an acetylene exchange reaction took place between $1 \mathrm{a}$ and 5-decyne to give $1 \mathrm{c}$ prior to the reaction with $\mathrm{Cl}^{-}$.

In a second experiment, 4-octyne (1 equiv) was added to a solution of $1 \mathrm{c}$ which was electrochemically generated from 5-decene and PhSSPh, and the mixture was reacted with $\mathrm{Bu}_{4} \mathrm{NCl}$. $2 \mathbf{j}$ was obtained as the major product $(94 \%)$ in addition to a small amount of 2 a $(2 \%)$.

These experiments revealed that in the reaction of 1 with $\mathrm{Cl}^{-}$path $b$ is faster than path $a$, although a small amount of $\mathbf{2}$ might be produced via $\mathbf{3}$ through path $a$ and its reverse reaction.

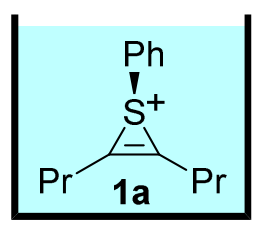

a) $\mathrm{Bu}=\mathrm{Bu}$

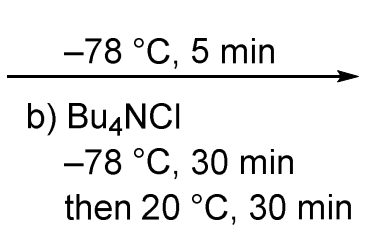

a) $\operatorname{Pr}=\operatorname{Pr}$

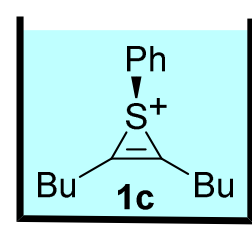

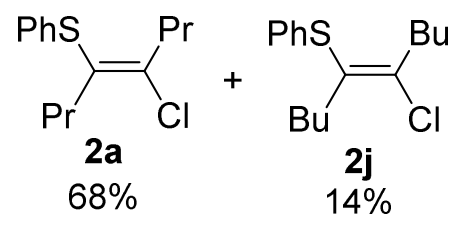

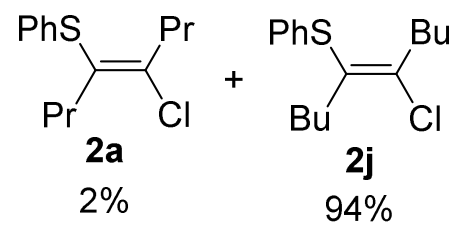

Figure 7. Reactions of 1 with $\mathrm{Cl}^{-}$in the presence of alkynes.

\section{Conclusions}

In conclusion, we show that thiirenium ions having no bulky substituent groups can be generated and accumulated in $\mathrm{CH}_{2} \mathrm{Cl}_{2}$ by electrochemical oxidation of disulfide in the presence of alkynes at low temperatures such as $-78{ }^{\circ} \mathrm{C}$. The thiirenium ions were successfully characterized by NMR, MS, and Raman spectroscopic analyses and exhibited two types of reactivity depending on the nature of nucleophiles. 


\section{Experimental Section}

General. ${ }^{1} \mathrm{H}$ and ${ }^{13} \mathrm{C}$ NMR spectra were recorded in $\mathrm{CDCl}_{3}$ on Varian Mercury plus-400 $\left({ }^{1} \mathrm{H}: 400 \mathrm{MHz},{ }^{13} \mathrm{C}: 100\right.$ $\mathrm{MHz}$ ) spectrometer, or JEOL ECA-600P spectrometer $\left({ }^{1} \mathrm{H}: 600 \mathrm{MHz},{ }^{13} \mathrm{C}: 150 \mathrm{MHz}\right)$ with tetramethylsilane as an internal standard unless otherwise noted. Mass spectra were obtained on JEOL JMS-SX102A mass spectrometer (EI). GC analysis was performed on a Shimadzu GC-2014 gas chromatograph equipped with a flame ionization detector using a fused silica capillary column (column, CBP1; $0.22 \mathrm{~mm} \times 25 \mathrm{~m}$ ). Merck precoated silica gel F254 plates (thickness $0.25 \mathrm{~mm}$ ) was used for thin-layer chromatography (TLC) analysis. Flash chromatography was carried out on silica gel (Kanto Chem. Co., Silica Gel N, spherical, neutral, 40-100 $\mu \mathrm{m})$ unless otherwise noted. All reactions were carried out under argon atmosphere unless otherwise noted. The anodic oxidation was carried out using an $\mathrm{H}$-type divided cell (4G glass filter) equipped with a carbon felt anode (Nippon Carbon GF-20-P21E, ca. $160 \mathrm{mg}$ for $0.25 \mathrm{mmol}$ scale, dried at $300{ }^{\circ} \mathrm{C} / 1 \mathrm{mmHg}$ for $3 \mathrm{~h}$ before use) and a platinum plate cathode $(10 \mathrm{~mm} \times 10 \mathrm{~mm}$ ) (Figure S1). Although we used a cell of our original design, similar electrochemical cells are commercially available at Adams \& Chittenden Scientific Glass (http://adamschittenden.com/gallery.html?category=4) and EC Frontier.,Inc. (http://www.ec-frontier.co.jp/VB9.html ). A Kikusui PMC350-0.2A was used as DC power supply for the electrolysis.

$\mathrm{Bu}_{4} \mathrm{NBF}_{4}$ was purchased from $\mathrm{TCl}$ and dried at $25^{\circ} \mathrm{C} / 1 \mathrm{mmHg}$ for $12 \mathrm{~h}$. Dichloromethane was washed with water, distilled from $\mathrm{P}_{2} \mathrm{O}_{5}$, redistilled from dried $\mathrm{K}_{2} \mathrm{CO}_{3}$ to remove a trace amount of acid, and stored over $4 \AA$ molecular sieves. Dichloromethane- $d_{2}\left(\mathrm{CD}_{2} \mathrm{Cl}_{2} \mathrm{D}-99.80 \%\right)$ was purchased and stored over molecular sieves $4 \mathrm{~A}$. Unless otherwise noted, all materials were obtained from commercial suppliers and used without further purification. Bis(4-fluorophenyl)disulfide was prepared according to a reported procedure. ${ }^{37,38}$ Compounds $\mathbf{2 a},{ }^{39} \mathbf{2} \mathbf{b},{ }^{40} \mathbf{2} \mathbf{c}^{39} \mathbf{2} \mathbf{d},{ }^{39} \mathbf{2} \mathrm{f}^{41} \mathbf{2} \mathbf{h}^{39}$ and $\mathbf{3} \mathbf{c}^{42}$ were oil, and were characterized by comparison of their ${ }^{1} \mathrm{H}$ NMR spectra with those reported in the literature.

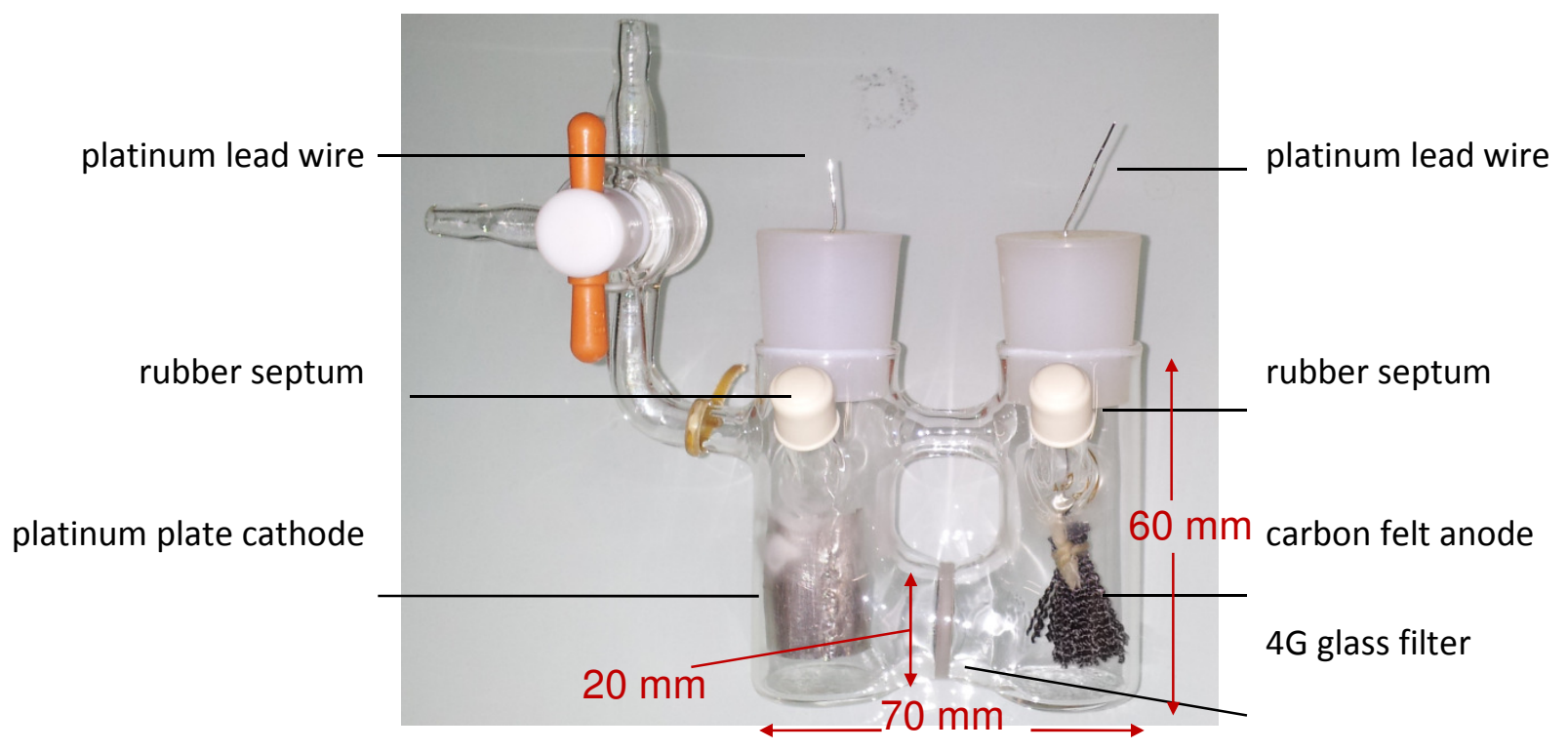

Figure 8. An H-type divided cell for electrolysis.

Generation and accumulation of thiirenium ion. The anodic oxidation was carried out in an H-type divided cell equipped with a carbon felt anode and a platinum plate cathode. In the anodic chamber was placed a solution of PhSSPh (0.5 equiv) and 4-octyne (1 equiv) in $0.3 \mathrm{M} \mathrm{Bu}_{4} \mathrm{PBF}_{4}, \mathrm{Bu}_{4} \mathrm{NB}\left(\mathrm{C}_{6} \mathrm{~F}_{5}\right)_{4}$, or $\mathrm{Bu}_{4} \mathrm{NBF}_{4}$ in $\mathrm{CH}_{2} \mathrm{Cl}_{2}(10$ 
$\mathrm{mL}$ ). In the cathodic chamber were placed $0.3 \mathrm{M} \mathrm{Bu}_{4} \mathrm{PBF}_{4}, \mathrm{Bu}_{4} \mathrm{NB}\left(\mathrm{C}_{6} \mathrm{~F}_{5}\right)_{4}$, or $\mathrm{Bu}_{4} \mathrm{NBF}_{4}$ in $\mathrm{CH}_{2} \mathrm{Cl}_{2}(10 \mathrm{~mL})$ and trifluoromethanesulfonic acid $(60 \mu \mathrm{l})$. The constant current electrolysis $(8.0 \mathrm{~mA})$ was carried out at $-78^{\circ} \mathrm{C}$ with magnetic stirring until $2.1 \mathrm{~F}$ of electricity was applied.

Reactions of thiirenium ion with nucleophiles. The electrolysis of PhSSPh $(27.3 \mathrm{mg}, 0.125 \mathrm{mmol})$ in the presence of 4-octyne $(28.6 \mathrm{mg}, 0.250 \mathrm{mmol})$ was carried out as described above. To a solution of the thiirenium ion thus generated in the anodic chamber was added a solution of nucleophile $(2.50 \mathrm{mmol})$ in $\mathrm{CH}_{2} \mathrm{Cl}_{2}$ at $-78{ }^{\circ} \mathrm{C}$ and the reaction mixture was stirred at $-78{ }^{\circ} \mathrm{C}$ for $30 \mathrm{~min}$, and then at $20{ }^{\circ} \mathrm{C}$ for $30 \mathrm{~min}$. The solution in the anodic chamber was collected and the solvent was removed under reduced pressure and the residue was quickly filtered through a short column $(2 \times 3 \mathrm{~cm})$ of silica gel to remove $\mathrm{Bu}_{4} \mathrm{NBF}_{4}$. After removal of the solvent under reduced pressure, the crude product was purified by flash chromatography and GPC to obtain the products.

\section{Reactions of thiirenium ion with nucleophiles}

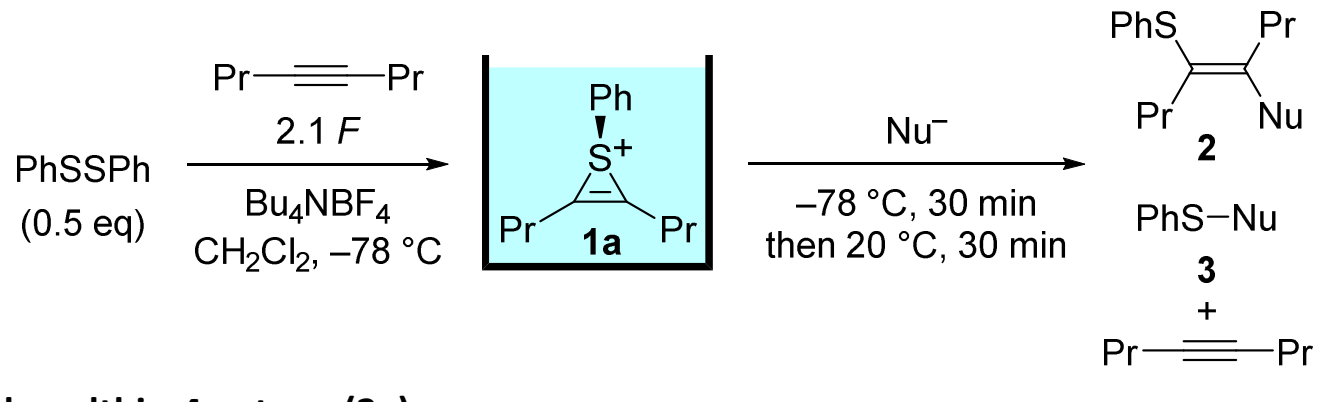

(E)-4-Chloro-5-phenylthio-4-octene (2a)

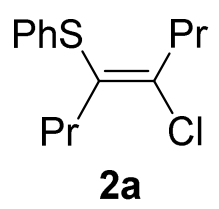

The electrolysis $(2.1 \mathrm{~F})$ of PhSSPh $(27.6 \mathrm{mg}, 0.126 \mathrm{mmol})$ in the presence of 4-octyne $(27.7 \mathrm{mg}, 0.251 \mathrm{mmol})$, and subsequent treatment with $2.5 \mathrm{M} \mathrm{Bu}{ }_{4} \mathrm{NCl} / \mathrm{CH}_{2} \mathrm{Cl}_{2}(1 \mathrm{~mL})$ gave the title compound (87\% yield). The yield was determined by GC analysis using hexadecane as internal standard.

(E)-4-Fluoro-5-phenylthio-4-octene (2b)

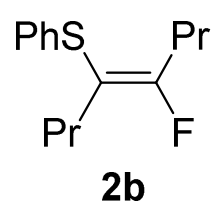

The electrolysis $(2.1 \mathrm{~F})$ of PhSSPh $(76.0 \mathrm{mg}, 0.348 \mathrm{mmol})$ in the presence of 4-octyne $(74.5 \mathrm{mg}, 0.676 \mathrm{mmol})$ followed by flash chromatography (hexane/EtOAc 100:0, then 10:3) gave the title compound (148.3 mg, $92 \%$ yield). 
(E)-4-Bromo-5-phenylthio-4-octene (2c)

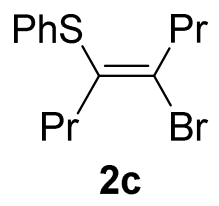

The electrolysis $(2.1 \mathrm{~F})$ of PhSSPh $(31.6 \mathrm{mg}, 0.145 \mathrm{mmol})$ in the presence of 4-octyne $(31.2 \mathrm{mg}, 0.283 \mathrm{mmol})$, and the subsequent treatment with $2.5 \mathrm{M} \mathrm{Bu}{ }_{4} \mathrm{NBr} / \mathrm{CH}_{2} \mathrm{Cl}_{2}(1 \mathrm{~mL})$ followed by a short column of silica gel (hexane/EtOAc 1:1) and GPC gave the title compound (61.5 mg, 82\%).

(E)-4-lodo-5-phenylthio-4-octene (2d)

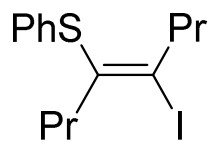

2d

The electrolysis $(2.1 \mathrm{~F})$ of PhSSPh $(31.5 \mathrm{mg}, 0.144 \mathrm{mmol})$ in the presence of 4-octyne $(31.7 \mathrm{mg}, 0.288 \mathrm{mmol})$, and the subsequent treatment with a solution of $\mathrm{Bu}_{4} \mathrm{NI}(923 \mathrm{mg}, 2.50 \mathrm{mmol})$ in $\mathrm{CH}_{2} \mathrm{Cl}_{2}(1.0 \mathrm{~mL})$ followed by a short column of silica gel (hexane/EtOAc 1:1) and GPC gave the title compound (55.7 $\mathrm{mg}, 69 \%)$.

(E)-4-(4-Nitrophenoxy)-5-phenylthio-4-octene (2e)

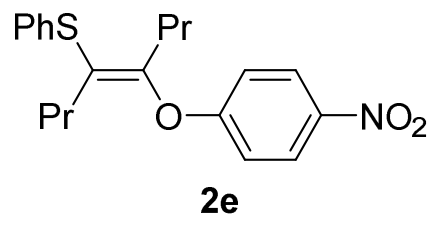

The electrolysis $(2.1 \mathrm{~F})$ of PhSSPh $(27.8 \mathrm{mg}, 0.127 \mathrm{mmol})$ in the presence of 4-octyne $(26.9 \mathrm{mg}, 0.244 \mathrm{mmol})$, and the subsequent treatment with a solution of $\mathrm{Bu}_{4} \mathrm{NO}\left(\mathrm{C}_{6} \mathrm{H}_{4}-p-\mathrm{NO}_{2}\right)(660 \mathrm{mg}, 1.74 \mathrm{mmol})$ in $\mathrm{CH}_{2} \mathrm{Cl}_{2}(4.0 \mathrm{~mL})$ followed by a short column of silica gel (hexane/EtOAc 1:1) and GPC gave the title compound (34.7 mg, $40 \%)$. ${ }^{1} \mathrm{H}$ NMR (400 MHz, CDCl $\left.)\right) \delta 8.24(\mathrm{~d}, J 9.3 \mathrm{~Hz}, 2 \mathrm{H}), 7.35-7.20(\mathrm{~m}, 4 \mathrm{H}), 7.02(\mathrm{~d}, J 9.3 \mathrm{~Hz}, 2 \mathrm{H}), 2.63(\mathrm{t}, \mathrm{J} 7.8 \mathrm{~Hz}, 2 \mathrm{H})$, $2.13(\mathrm{t}, J 7.7 \mathrm{~Hz}, 2 \mathrm{H}), 1.58-1.42(\mathrm{~m}, 4 \mathrm{H}), 0.92(\mathrm{t}, J 7.4 \mathrm{~Hz}, 3 \mathrm{H}), 0.78(\mathrm{t}, J 7.5 \mathrm{~Hz}, 3 \mathrm{H}) ;{ }^{13} \mathrm{C} \mathrm{NMR}\left(100 \mathrm{MHz} \mathrm{CDCl}_{3}\right) \delta$ 161.7, 154.7, 142.4, 135.0, 129.08, 129.07, 126.4, 126.1, 124.5, 116.0, 32.0, 31.8, 21.3, 20.9, 13.67, 13.63; LRMS (EI) $m / z 357\left(\mathrm{M}^{+}\right)$; HRMS (EI) calcd for $\mathrm{C}_{20} \mathrm{H}_{23} \mathrm{NO}_{3} \mathrm{~S}\left(\mathrm{M}^{+}\right)$: 357.1399, found: 357.1391 .

(E)-4-Acetoxy-5-phenylthio-4-octene (2f)

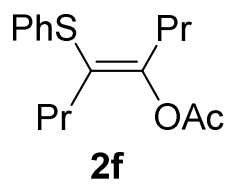


The electrolysis $(2.1 \mathrm{~F})$ of PhSSPh $(27.2 \mathrm{mg}, 0.125 \mathrm{mmol})$ in the presence of 4-octyne $(25.6 \mathrm{mg}, 0.232 \mathrm{mmol})$, and the subsequent treatment with a solution of $\mathrm{Bu}_{4} \mathrm{NOAc}(754 \mathrm{mg}, 2.50 \mathrm{mmol})$ in $\mathrm{CH}_{2} \mathrm{Cl}_{2}(1.0 \mathrm{~mL})$ followed by a short column of silica gel (hexane/EtOAc 1:1) and GPC gave the title compound (39.2 $\mathrm{mg}, 61 \%$ ).

\section{(E)-4-Trifluoromethanesulfonyloxy-5-phenylthio-4-octene (2g)}

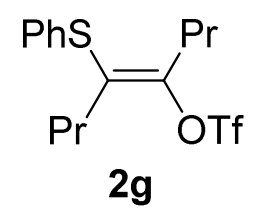

The electrolysis $(2.1 \mathrm{~F})$ of PhSSPh $(27.4 \mathrm{mg}, 0.126 \mathrm{mmol})$ in the presence of 4-octyne $(27.6 \mathrm{mg}, 0.250 \mathrm{mmol})$, and the subsequent treatment with a solution of $\mathrm{Bu}_{4} \mathrm{NOTf}(979 \mathrm{mg}, 2.50 \mathrm{mmol})$ in $\mathrm{CH}_{2} \mathrm{Cl}_{2}(1.0 \mathrm{~mL})$ followed by a short column of silica gel (hexane/EtOAc $1: 1$ ) and GPC gave the title compound (41.5 mg, 45\%). ${ }^{1} \mathrm{H}$ NMR (400 $\mathrm{MHz}_{\mathrm{CDCl}}$ ) $\delta 7.33-7.21(\mathrm{~m}, 5 \mathrm{H}), 2.78(\mathrm{t}, J 7.5 \mathrm{~Hz}, 2 \mathrm{H}), 2.27(\mathrm{t}, J 7.5 \mathrm{~Hz}, 2 \mathrm{H}), 1.67-1.49(\mathrm{~m}, 4 \mathrm{H}), 0.96(\mathrm{t}, J 7.5 \mathrm{~Hz}$, $3 \mathrm{H}), 0.84(\mathrm{t}, J 7.5 \mathrm{~Hz}, 3 \mathrm{H}) ;{ }^{13} \mathrm{C} \mathrm{NMR}\left(100 \mathrm{MHz}, \mathrm{CDCl}_{3}\right) \delta 151.4,133.4,129.9,129.5,129.2,126.9,118.4\left(\mathrm{q}, J_{\mathrm{C}-\mathrm{F}}=\right.$ $36.1 \mathrm{~Hz}), 33.6,32.5,21.1,20.3,13.4,13.2$; LRMS (EI) $\mathrm{m} / \mathrm{z} 368\left(\mathrm{M}^{+}\right)$; HRMS (EI) calcd for $\mathrm{C}_{15} \mathrm{H}_{19} \mathrm{~F}_{3} \mathrm{O}_{3} \mathrm{~S}_{2}\left(\mathrm{M}^{+}\right)$: 368.0728 , found: 368.0730 .

(E)-4-Thiocyanato-5-phenylthio-4-octene (2h)

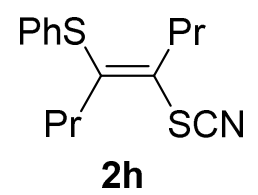

The electrolysis $(2.1 \mathrm{~F})$ of PhSSPh $(27.4 \mathrm{mg}, 0.126 \mathrm{mmol})$ in the presence of 4-octyne $(27.6 \mathrm{mg}, 0.250 \mathrm{mmol})$, and the subsequent treatment with the solution of $\mathrm{Bu}_{4} \mathrm{NSCN}\left(752 \mathrm{mg}, 2.50 \mathrm{mmol}\right.$ ) in $\mathrm{CH}_{2} \mathrm{Cl}_{2}$ (1.0 mL) followed by a short column of silica gel (hexane/EtOAc 1:1) and GPC gave the title compound ( $46.3 \mathrm{mg}, 67 \%)$.

\section{5-(Phenylthio)octan-4-one (4)}

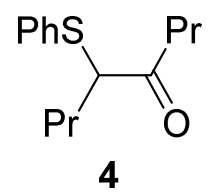

The electrolysis $(2.1 \mathrm{~F})$ of PhSSPh $(24.3 \mathrm{mg}, 0.111 \mathrm{mmol})$ in the presence of 4-octyne $(23.2 \mathrm{mg}, 0.27 \mathrm{mmol})$, and the subsequent treatment with $\mathrm{CH}_{3} \mathrm{OH}(81.2 \mathrm{mg}, 2.53 \mathrm{mmol})$ followed by flash chromatography (hexane/EtOAc 100:0, then 5:1) to the title compound (32.7 mg, $66 \%$ ). $\left.{ }^{1} \mathrm{H} \mathrm{NMR} \mathrm{(400} \mathrm{MHz,} \mathrm{CDCl}_{3}\right) \delta 7.37-7.33$ $(\mathrm{m}, 2 \mathrm{H}), 7.31-7.22(\mathrm{~m}, 3 \mathrm{H}), 3.64(\mathrm{t}, J 7.5 \mathrm{~Hz}, 1 \mathrm{H}), 2.55(\mathrm{t}, J 7.7 \mathrm{~Hz}, 2 \mathrm{H}), 1.85-1.75(\mathrm{~m}, 1 \mathrm{H}), 1.72-1.62(\mathrm{~m}, 1 \mathrm{H})$, 1.60-1.53 (m, 2H), 1.51-1.44 (m, 1H), 1.42-1.31 (m, 1H), $0.92(\mathrm{t}, J 7.5 \mathrm{~Hz}, 3 \mathrm{H}), 0.88(\mathrm{t}, J 7.5 \mathrm{~Hz}, 3 \mathrm{H}) ;{ }^{13} \mathrm{C} \mathrm{NMR}$ $\left(100 \mathrm{MHz}_{1} \mathrm{CDCl}_{3}\right) \delta 207.5,133.3,132.3,129.0,127.7,56.7,41.2,32.5,20.6,17.3,13.77,13.72 ;$ LRMS (EI) m/z $236\left(\mathrm{M}^{+}\right)$; HRMS (EI) calcd for $\mathrm{C}_{14} \mathrm{H}_{20} \mathrm{OS}\left(\mathrm{M}^{+}\right)$: 236.1235, found: 236.1231 . 
(E)-4-Phenylthio-5-phenylethynyl-4-octene (2i)

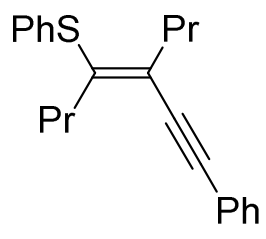

$2 \mathbf{i}$

The electrolysis $(2.1 \mathrm{~F})$ of PhSSPh $(27.5 \mathrm{mg}, 0.126 \mathrm{mmol})$ in the presence of 4-octyne $(27.6 \mathrm{mg}, 0.25 \mathrm{mmol})$, and the subsequent treatment with the solution of $1.0 \mathrm{M}$ lithium phenylacetylide/THF $(2.5 \mathrm{~mL})$ followed by a short column of silica gel (hexane/EtOAc 1:1) and GPC gave $\mathbf{2} \mathbf{i}(10.8 \mathrm{mg}, 14 \%)$ and $3 \mathrm{3a}(31.8 \mathrm{mg}, 60 \%) .{ }^{1} \mathrm{H} \mathrm{NMR}$

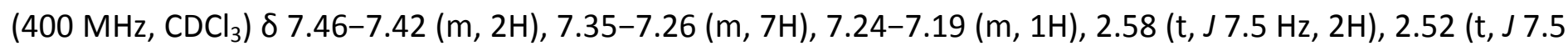
$\mathrm{Hz}, 2 \mathrm{H}), 1.71-1.62(\mathrm{~m}, 2 \mathrm{H}), 1.61-1.52(\mathrm{~m}, 2 \mathrm{H}), 0.98(\mathrm{t}, J 7.5 \mathrm{~Hz}, 3 \mathrm{H}), 0.88(\mathrm{t}, J 7.5 \mathrm{~Hz}, 3 \mathrm{H}) ;{ }^{13} \mathrm{C} \mathrm{NMR}(100 \mathrm{MHz}$, $\left.\mathrm{CDCl}_{3}\right) \delta 142.5,134.9,131.3,130.6,128.9,128.3,128.0,126.9,126.6,123.7,94.4,89.3,37.0,36.2,22.1,22.0$, 13.69, 13.62; LRMS (EI) m/z $320\left(\mathrm{M}^{+}\right)$; HRMS (EI) calcd for $\mathrm{C}_{22} \mathrm{H}_{24} \mathrm{~S}\left(\mathrm{M}^{+}\right)$: 320.1599 , found: 320.1598.

We could not determine the stereochemistry of $\mathbf{2} \mathbf{i}$ by NOE measurement because the chemical shift of the protons of two methylene groups next to the alkene moiety are very close ( 2.52 and $2.58 \mathrm{ppm}$ ).

Phenyl(phenylethynyl)sulfane (3a)

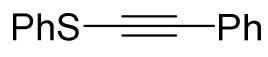

$3 a$

${ }^{1} \mathrm{H}$ NMR $\left(400 \mathrm{MHz}, \mathrm{CDCl}_{3}\right) \delta$ 7.53-7.47 (m, 4H), 7.37-7.33 (m, 5H), 7.25-7.21 (m, $\left.1 \mathrm{H}\right) ;{ }^{13} \mathrm{C} \mathrm{NMR} \mathrm{(100} \mathrm{MHz,}$ $\mathrm{CDCl}_{3}$ ) $\delta 132.9,131.7,129.2,128.6,128.4,126.5,126.2,122.9,97.9,75.4 ;$ LRMS (EI) m/z 210 (M ${ }^{+}$); HRMS (EI) calcd for $\mathrm{C}_{14} \mathrm{H}_{10} \mathrm{~S}\left(\mathrm{M}^{+}\right): 210.0503$, found: 210.0494 .

Methyl 2-methyl-2-(phenylthio)propionate (3b)<smiles>COC(=O)C(C)(C)Sc1ccccc1</smiles>

$3 b$

The electrolysis $(2.1 \mathrm{~F})$ of PhSSPh $(27.5 \mathrm{mg}, 0.126 \mathrm{mmol})$ in the presence of 4-octyne $(27.6 \mathrm{mg}, 0.250 \mathrm{mmol})$, and subsequent treatment with dimethylketene methyl trimethylsilyl acetal ( $436 \mathrm{mg}, 2.50 \mathrm{mmol}$ ) followed by a short column of silica gel (hexane/EtOAc 1:1) and GPC gave the title compound (26.6 mg, 50\%). ${ }^{1} \mathrm{H}$ NMR (400 $\left.\mathrm{MHz}_{2} \mathrm{CDCl}_{3}\right) \delta 7.47-7.44(\mathrm{~m}, 2 \mathrm{H}), 7.40-7.30(\mathrm{~m}, 3 \mathrm{H}), 3.66(\mathrm{~s}, 3 \mathrm{H}), 1.49(\mathrm{~s}, 6 \mathrm{H}) ;{ }^{13} \mathrm{C} \mathrm{NMR}\left(100 \mathrm{MHz} \mathrm{CDCl}_{3}\right) \delta$ 174.4, 136.7, 131.4, 129.4, 128.6, 52.2, 51.0, 25.8; LRMS (EI) $\mathrm{m} / z 210\left(\mathrm{M}^{+}\right.$); HRMS (EI) calcd for $\mathrm{C}_{11} \mathrm{H}_{14} \mathrm{O}_{2} \mathrm{~S}$ $\left(\mathrm{M}^{+}\right): 210.0715$, found: 210.0714 . 
Diethyl(phenylthio)amine (3c)

$\mathrm{PhS}-\mathrm{NEt}_{2}$

$3 c$

The electrolysis $(2.1 \mathrm{~F})$ of PhSSPh $(27.6 \mathrm{mg}, 0.126 \mathrm{mmol})$ in the presence of 8-hexadecyne $(56.1 \mathrm{mg}, 0.252$ $\mathrm{mmol}$ ), and subsequent treatment with diethylamine (185 $\mathrm{mg}, 2.53 \mathrm{mmol}$ ) followed by a short column of silica gel (hexane/EtOAc 1:1) and GPC gave the title compound (37.3 mg, 82\%) and 8-hexadecyne (52.9 mg, $94 \%)$.

Thermal stability. After generating thionium ion from PhSSPh $(27.3 \mathrm{mg}, 0.125 \mathrm{mmol})$ and 4-octyne (28.6 mg, $0.25 \mathrm{mmol})$ at $-78{ }^{\circ} \mathrm{C}$ as described above, the solution was stirred at $T^{\circ} \mathrm{C}(T=-78,-60,-40,-20$, and 0$)$ for 30 min. The solution was recooled to $-78{ }^{\circ} \mathrm{C}$, added $\mathrm{Bu}_{4} \mathrm{NCl}(2.5 \mathrm{mmol})$ in $\mathrm{CH}_{2} \mathrm{Cl}_{2}$ and stirred at $-78{ }^{\circ} \mathrm{C}$ for $30 \mathrm{~min}$ and then at $20^{\circ} \mathrm{C}$ for $30 \mathrm{~min}$. The solvent was removed under reduced pressure and the residue was quickly filtered through a short column $(2 \times 3 \mathrm{~cm})$ of silica gel to remove $\mathrm{Bu}_{4} \mathrm{NBF}_{4}$. The silica gel was washed with hexane/EtOAc 1:1. After removal of the solvent under reduced pressure, the crude product was analyzed by gas chromatography.

Reference reaction. In the anodic chamber were placed 4-octyne or 5-decyne $(0.25 \mathrm{mmol})$, and $\mathrm{PhSSPh}(0.125$ mmol), $\mathrm{Bu}_{4} \mathrm{NBF}_{4}(3.0 \mathrm{mmol})$, and $\mathrm{CH}_{2} \mathrm{Cl}_{2}(10 \mathrm{~mL})$. In the cathodic chamber were placed trifluoromethanesulfonic acid $(60 \mu \mathrm{L}), \mathrm{Bu}_{4} \mathrm{NBF}_{4}(3.0 \mathrm{mmol})$ and $\mathrm{CH}_{2} \mathrm{Cl}_{2}(10 \mathrm{~mL})$. The constant current electrolysis $(8.0 \mathrm{~mA})$ was carried out at $-78{ }^{\circ} \mathrm{C}$ with magnetic stirring until $2.1 \mathrm{~F}$ of electricity was passed. To the anodic chamber was added another alkyne $(0.25 \mathrm{mmol})$. The solution was stirred for $10 \mathrm{~min}$ at $-78^{\circ} \mathrm{C}$. To the anodic chamber was added $2.5 \mathrm{M} \mathrm{Bu}{ }_{4} \mathrm{NCl} / \mathrm{CH}_{2} \mathrm{Cl}_{2}(1 \mathrm{~mL})$, and to the cathodic chamber $\mathrm{CH}_{2} \mathrm{Cl}_{2}(1 \mathrm{~mL})$ was added at $-78{ }^{\circ} \mathrm{C}$. The solution was stirred for $30 \mathrm{~min}$ at $-78{ }^{\circ} \mathrm{C}$, and then $30 \mathrm{~min}$ at $20{ }^{\circ} \mathrm{C}$. The solution in the anodic chambers was collected and the solvent was removed under reduced pressure. The residue was filtered through a short column $(2 \times 4 \mathrm{~cm})$ of silica gel to remove $\mathrm{Bu}_{4} \mathrm{NBF}_{4}$ by using hexane/EtOAc $(1: 1 \mathrm{v} / \mathrm{v})$ as an eluent. After removal of the solvent under reduced pressure the crude product was analyzed by $\mathrm{GC}$ using tetradecane as an internal standard.

(E)-5-Chloro-6-phenylthio-5-hexene (2j)

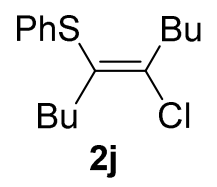

In the anodic chamber were placed 5-decyne $(34.6 \mathrm{mg}, 0.25 \mathrm{mmol})$ and diphenyl disulfide $(27.5 \mathrm{mg}, 0.126$ $\mathrm{mmol})$. Electrochemical oxidation $(2.1 \mathrm{~F})$ and subsequent addition of the solution of $2.5 \mathrm{M} \mathrm{Bu} \mathrm{BCl}_{4} / \mathrm{CH}_{2} \mathrm{Cl}_{2}(1$ $\mathrm{mL}$ ) followed by a short column of silica gel (hexane/EtOAc 1:1) gave the crude of the title compound. After removal of the solvent under reduced pressure the crude product was analyzed by GC using tetradecane as an internal standard (99\% yield). ${ }^{1} \mathrm{H}$ NMR $\left(400 \mathrm{MHz}, \mathrm{CDCl}_{3}\right) \delta 7.27-7.19(\mathrm{~m}, 4 \mathrm{H}), 7.17-7.12(\mathrm{~m}, 1 \mathrm{H}), 2.80(\mathrm{t}, J 7.5$ $\mathrm{Hz}, 2 \mathrm{H}), 2.37(\mathrm{t}, J 7.9 \mathrm{~Hz}, 2 \mathrm{H}), 1.62-1.54(\mathrm{~m}, 4 \mathrm{H}), 1.53-1.45(\mathrm{~m}, 4 \mathrm{H}), 0.91(\mathrm{t}, J 7.2 \mathrm{~Hz}, 3 \mathrm{H}), 0.84(\mathrm{t}, J 7.3 \mathrm{~Hz}, 3 \mathrm{H})$;

${ }^{13} \mathrm{C} \mathrm{NMR}\left(100 \mathrm{MHz}, \mathrm{CDCl}_{3}\right) \delta 139.8,135.5,129.5,128.9,128.8,126.1,37.0,33.8,30.1,29.9,22.2,21.8,13.90$, 13.89; LRMS (EI) $m / z 282\left(\mathrm{M}^{+}\right)$; HRMS (EI) calcd for $\mathrm{C}_{16} \mathrm{H}_{27} \mathrm{ClS}\left(\mathrm{M}^{+}\right): 282.1209$, found: 282.1208. 
NMR analyses. A solution of thiirenium ion 1a generated and accumulated from PhSSPh (49.4 mg, 0.226 mmol) and 4-octyne (48.5 mg, $0.440 \mathrm{mmol})$ in $0.3 \mathrm{M} \mathrm{Bu}_{4} \mathrm{PBF}_{4}$ in $\mathrm{CD}_{2} \mathrm{Cl}_{2}(6.0 \mathrm{~mL})$ was transferred to Ar-flushed NMR tubes at $-78{ }^{\circ} \mathrm{C}$ by Ar-flushed $1 \mathrm{~mL}$ syringe cooled with dry ice. NMR measurements were carried out using JEOL ECA-600P spectrometer $\left({ }^{1} \mathrm{H}: 600 \mathrm{MHz},{ }^{13} \mathrm{C}: 150 \mathrm{MHz}\right)$. Spectra so obtained are presented in the Supplementary File.

MS analyses; typical procedure. In the anodic chamber were placed 4-octyne (118.6 mg, $1.08 \mathrm{mmol}), \mathrm{PhSSPh}$ (114.6 mg, $0.525 \mathrm{mmol}), \mathrm{Bu}_{4} \mathrm{NB}\left(\mathrm{C}_{6} \mathrm{~F}_{5}\right)_{4}(923.9 \mathrm{mg}, 1.0 \mathrm{mmol})$, and $\mathrm{CH}_{2} \mathrm{Cl}_{2}(10 \mathrm{~mL})$. In the cathodic chamber were placed trifluoromethanesulfonic acid $(120 \mu \mathrm{L}, 1.37 \mathrm{mmol}), \mathrm{Bu}_{4} \mathrm{NBF}_{4}(926 \mathrm{mg}, 1.0 \mathrm{mmol}), \mathrm{and}^{\mathrm{C}} \mathrm{CH}_{2} \mathrm{Cl}_{2}(10$ $\mathrm{mL})$. The constant current electrolysis $(15.0 \mathrm{~mA})$ was carried out at $-78{ }^{\circ} \mathrm{C}$ with magnetic stirring until $2.1 \mathrm{~F}$ of electricity was passed. The reaction mixture of the anodic chamber was analyzed by CSI-MS (spray temperature; $\left.0{ }^{\circ} \mathrm{C}\right)$ : HRMS (CSI) $\mathrm{m} / z$ calcd for $\mathrm{C}_{14} \mathrm{H}_{19} \mathrm{~S}^{+}\left(\mathrm{M}^{+}\right)$: 219.1202 , found: 219.1209 .

Raman analyses. A laser beam from a fiber-coupled output of cw laser, Toptica XTRA, $250 \mathrm{~mW}$ at $785 \mathrm{~nm}$, was conducted through the solution in the anodic chamber of the electrochemical cell. Scattered light was collected in the direction perpendicular to the axis of the laser beam by using a combination of quartz lenses focusing the light on the surface of the entrance cross section of the bundle of forty optical fibers with a 100 $\mu \mathrm{m}$ diameter for each. The optical components were contained in a vacuum-tight glass tube sealed with rubber $o$-rings and partly dipped into the reactant solution. The electrochemical cell was independently purged with $\mathrm{N}_{2}$ gas to avoid humidity in air. For the measurement, the vacuum seal of the optical component was crucial in avoiding frost, which scatters both the excitation and signal beams.

The collected light was conducted through the optical fibers to a spectrometer for dispersion, Acton $320 \mathrm{PI}$ (1200 G/mm blazed at $500 \mathrm{~nm}$ or $600 \mathrm{G} / \mathrm{mm}$ blazed at $1000 \mathrm{~nm})$, and detected by using a liquid-nitrogen cooled CCD array detector, PyLoN:256-OE $1024 \times 256$ pixels of $26 \times 26 \mu \mathrm{m}^{2}$. To minimize stray light, a sharpedge long-pass filter, Semrock RazorEdge $785 \mathrm{R}$ (o.d. $<10^{-6}$ at $785 \mathrm{~nm}$ ), was placed in front of the entrance slit of the spectrometer, where the image of the exit cross section of the fiber bundle with vertically aligned forty optical fibers was focused. Spectra were accumulated for 6 min $40 \mathrm{sec}$ (a 4-sec exposure time by 100 times accumulation) for each and redundantly stored one by one for 4 hours (400 sec by 60 spectra) during the electrolysis. Spectral resolution was $0.2 \mathrm{~nm}$, which corresponds to $\sim 3 \mathrm{~cm}^{-1}$ at $815 \mathrm{~nm}$ where a Raman band of $470 \mathrm{~cm}^{-1}$ was observed.

DFT calculations. DFT calculations were conducted with the Gaussian 09 program. $^{43}$ All geometry optimizations were carried out at the B3LYP level of density functional theory with the 6-31G(d) basis set. The bond order and s-character were obtained by the natural bond orbital (NBO) analysis. See Supplementary file.

\section{Acknowledgements}

This work was supported by the JSPS (KAKENHI Grants JP26220804, and JP16K14057).

\section{Supplementary Material}

Experimental procedures and spectroscopic data for new compounds.

\section{References and Notes}

1. Capozzi, G.; Lucchini, V.; Modena, G. Res. Chem. Intermed. 1979, 2, 347. https://doi.org/10.1007/BF03156004 
2. Capozzi, G.; De Lucchi, O.; Lucchini, V.; Modena, G. J. Chem. Soc., Chem. Commun. 1975, 248. https://doi.org/10.1039/c39750000248

3. Capozzi, G.; Lucchini, V.; Modena, G.; Scrimin, P. Tetrahedron Lett. 1977, 18, 911. https://doi.org/10.1016/S0040-4039(01)92789-3

4. Capozzi, G.; Da Col. L.; Lucchini, V.; Modena, G.; Valle, G. J. Chem. Soc., Perkin Trans. 2 1980, 68. https://doi.org/10.1039/p29800000068

5. Lucchini, V.; Modena, G. Valle, G.; Capozzi, G. J. Org. Chem. 1981, 46, 4720. https://doi.org/10.1021/jo00336a019

6. $\quad$ Destro, R.; Lucchini, V.; Modena, G.; Pasquato, L. J. Org. Chem. 2000, 65, 3367. https://doi.org/10.1021/jo9917310

7. Poleschner, H.; Seppelt, K. Angew. Chem., Int. Ed. 2013, 52, 12838. https://doi.org/10.1002/anie.201307161

8. In ref 3, dimethylacetylene was reacted with methanesulfenyl chloride and antimony pentachloride in dichloromethane frozen at $-120^{\circ} \mathrm{C}$ followed by slow warming to $-80{ }^{\circ} \mathrm{C}$ to give precipitation of trimethylthiirenium hexachloroantimonate. However, we cannot evaluate the stability of the thiirenium ion because the yield of the thiirenium ion was not reported.

9. Moeller, K. D. Tetrahedron 2000, 56, 9527. https://doi.org/10.1016/S0040-4020(00)00840-1

10. Sperry, J. B.; Wright, D. L. Chem. Soc. Rev. 2006, 35, 605. https://doi.org/10.1039/b512308a

11. Yoshida, J.; Kataoka, K.; Horcajada, R.; Nagaki, A. Chem. Rev. 2008, 108, 2265. https://doi.org/10.1021/cr0680843

12. Frontana-Uribe, B. A.; Little, R. D.; Ibanez, J. G.; Palma, A.; Vasquez-Medrano, R. Green Chem. 2010, 12, 2099.

https://doi.org/10.1039/c0gc00382d

13. Ogawa, K. A.; Boydston, A. J. Chem. Lett. 2015, 44, 10.

https://doi.org/10.1246/cl.140915

14. Horn, E. J.; Rosen, B. R.; Baran, P. S. ACS Cent. Sci. 2016, 2, 302.

https://doi.org/10.1021/acscentsci.6b00091

15. Chiba, K.; Okada, Y. Curr. Opin. Electrochem. 2017, 2, 53.

https://doi.org/10.1016/i.coelec.2017.03.014

16. Horn, E. J.; Rosen, B. R.; Chen, Y.; Tang, J.; Chen, K.; Eastgate, M. D.; Baran, P. S. Nature, 2016, 533, 77. https://doi.org/10.1038/nature17431

17. Hayashi, R.; Shimizu, A.; Yoshida, J. J. Am. Chem. Soc. 2016, 138, 8400. https://doi.org/10.1021/jacs.6b05273

18. Llorente, M. J.; Nguyen, B. H.; Kubiak, C. P.; Moeller, K. D. J. Am. Chem. Soc. 2016, 138, 15110. https://doi.org/10.1021/jacs.6b08667

19. Yoshida, J.; Suga, S.; Suzuki, S.; Kinomura, N.; Yamamoto, A.; Fujiwara, K. J. Am. Chem. Soc. 1999, 121, 9546.

https://doi.org/10.1021/ja9920112

20. Yoshida, J.; Suga, S. Chem. Eur. J. 2002, 8, 2651. https://doi.org/10.1002/1521-3765(20020617)8:12<2650::AID-CHEM2650>3.0.CO;2-S

21. Yoshida, J.; Ashikari, Y.; Matsumoto, K.; Nokami, T. J. Synth. Org. Chem., Jpn. 2013, 71, 1136. https://doi.org/10.5059/yukigoseikyokaishi.71.1136 
22. Suga, S.; Matsumoto, K.; Ueoka, K.; Yoshida, J. J. Am. Chem. Soc. 2006, 128, 7710. https://doi.org/10.1021/ja0625778

23. Fujie, S.; Matsumoto, K.; Suga, S.; Nokami, T.; Yoshida, J. Tetrahedron 2010, 66, 2823. https://doi.org/10.1016/j.tet.2010.02.049

24. Matsumoto, K.; Suga, S.; Yoshida, J. Org. Biomol. Chem. 2011, 9, 2586. https://doi.org/10.1039/c0ob01070g

25. Matsumoto, K.; Kozuki, Y.; Ashikari, Y.; Suga, S.; Kashimura, S.; Yoshida, J. Tetrahedron Lett. 2012, 53, 1916. https://doi.org/10.1016/j.tetlet.2012.01.131

26. Matsumoto, K.; Sanada, T.; Shimazaki, H.; Shimada, K.; Hagiwara, S.; Fujie, S.; Ashikari, Y.; Suga, S.; Kashimura, S.; Yoshida, J. Asian J. Org. Chem. 2013, 2, 325. https://doi.org/10.1002/ajoc.201300017

27. Although $\mathrm{Bu}_{4} \mathrm{~N}^{+}$is generally used as a supporting electrolyte, protons of $\mathrm{Bu}_{4} \mathrm{~N}^{+}$were overlapped with the protons of $1 \mathrm{a}$ at 2.95-3.10 ppm. Therefore, $\mathrm{Bu}_{4} \mathrm{PBF}_{4}$ was used as the supporting electrolyte.

28. Yamaguchi, K. J. Mass Spectrom. 2003, 38, 473. https://doi.org/10.1002/jms.488

29. Compound 1 a generated in $\mathrm{Bu}_{4} \mathrm{NBF}_{4} / \mathrm{CH}_{2} \mathrm{Cl}_{2}$ was not observed by $\mathrm{MS}$ measurement probably because of the presence of $\mathrm{BF}_{4}{ }^{-}$, which reacts with $\mathbf{1 a}$ to give $\mathbf{2} \mathbf{b}$.

30. Matsumoto, K.; Miyamoto, Y.; Shimada, K.; Morisawa, Y.; Zipse, H.; Suga, S.; Yoshida, J.; Kashimura, S.; Wakabayashi, T. Chem. Commun. 2015, 51, 13106. https://doi.org/10.1039/C5CC03585F

31. Marui, T.; Kajita, S.; Katayama, Y.; Chiba, K. Electrochem. Commun. 2007, 9, 1331. https://doi.org/10.1016/j.elecom.2007.01.040

32. The use of PhSSPh caused precipitation during the electrochemical oxidation, which disturbed the Raman analysis.

33. Scott, A. P.; Radom, L. J. Phys. Chem. 1996, 100, 16502.

https://doi.org/10.1021/ip960976r

34. Poleschner, H. Seppelt, K. Angew. Chem., Int. Ed. 2008, 47, 6461

https://doi.org/10.1002/anie.200801691

35. Suga, S.; Suzuki, S.; Yamamoto, A.; Yoshida, J. J. Am. Chem. Soc. 2000, 122, 10244. https://doi.org/10.1021/ja002123p

36. Mayr, H.; Breugst, M.; Ofial, A. R. Angew. Chem., Int. Ed. 2011, 50, 6470. https://doi.org/10.1002/anie.201007100

37. Hirano, M.; Yakabe, S.; Monobe, H.; Morimoto, T. J. Chem. Res. (S) 1998, 472.

38. Becker, D. P.; Villamil, C. I.; Barta, T. E.; Bedell, L. J.; Boehm, T. L.; DeCrescenzo, G. A.; Freskos, J. N.; Getman, D. P.; Hockerman, S.; Heintz, R.; Howard, S. C.; Li, M. H.; McDonald, J. J.; Carron, C. P.; FunckesShippy, C. L.; Mehta, P. P.; Munie, G. E.; Swearingen, C. A. J. Med. Chem., 2005, 48, 6713. https://doi.org/10.1021/jm0500875

39. Taniguchi, N. Tetrahedron 2009, 65, 2782 https://doi.org/10.1016/i.tet.2009.01.094

40. Benati, L.; Montevecchi, P. C.; Spagnolo, P. J. Chem. Soc. Perkin Trans. 1 1990, 1691. https://doi.org/10.1039/P19900001691

41. Benati, L.; Casarini, D.; Montevecchi, P. C. Spagnolo, P. J. Chem. Soc. Perkin Trans. 1 1989, 1113. https://doi.org/10.1039/P19890001113 
42. Shiro, D.; Fujiwara, S.; Tsuda, S.; Iwasaki, T.; Kuniyasu, H.; Kambe, N. Tetrahedron Lett. 2015, 56, 1531. https://doi.org/10.1016/j.tetlet.2015.01.096

43. Gaussian 09, Revision C.01, Frisch, M. J.; Trucks, G. W.; Schlegel, H. B.; Scuseria, G. E.; Robb, M. A.; Cheeseman, J. R.; Scalmani, G.; Barone, V.; Mennucci, B.; Petersson, G. A.; Nakatsuji, H.; Caricato, M.; Li, X.; Hratchian, H. P.; Izmaylov, A. F.; Bloino, J.; Zheng, G.; Sonnenberg, J. L.; Hada, M.; Ehara, M.; Toyota, K.; Fukuda, R.; Hasegawa, J.; Ishida, M.; Nakajima, T.; Honda, Y.; Kitao, O.; Nakai, H.; Vreven, T.; Montgomery, Jr., J. A.; Peralta, J. E.; Ogliaro, F.; Bearpark, M.; Heyd, J. J.; Brothers, E.; Kudin, K. N.;Staroverov, V. N.; Kobayashi, R.; Normand, J.; Raghavachari, K.; Rendell, A.; Burant, J. C.; lyengar, S. S.; Tomasi, J.; Cossi, M.; Rega, N.; Millam, J. M.; Klene, M.; Knox, J. E.; Cross, J. B.; Bakken, V.; Adamo, C.; Jaramillo, J.; Gomperts, R.; Stratmann, R. E.; Yazyev, O.; Austin, A. J.; Cammi, R.; Pomelli, C.; Ochterski, J. W.; Martin, R. L.; Morokuma, K.; Zakrzewski, V. G.; Voth, G. A.; Salvador, P.; Dannenberg, J. J.; Dapprich, S.; Daniels, A. D.; Farkas, O.; Foresman, J. B.; Ortiz, J. V.; Cioslowski, J.; Fox, D. J. Gaussian, Inc., Wallingford CT, 2010. 